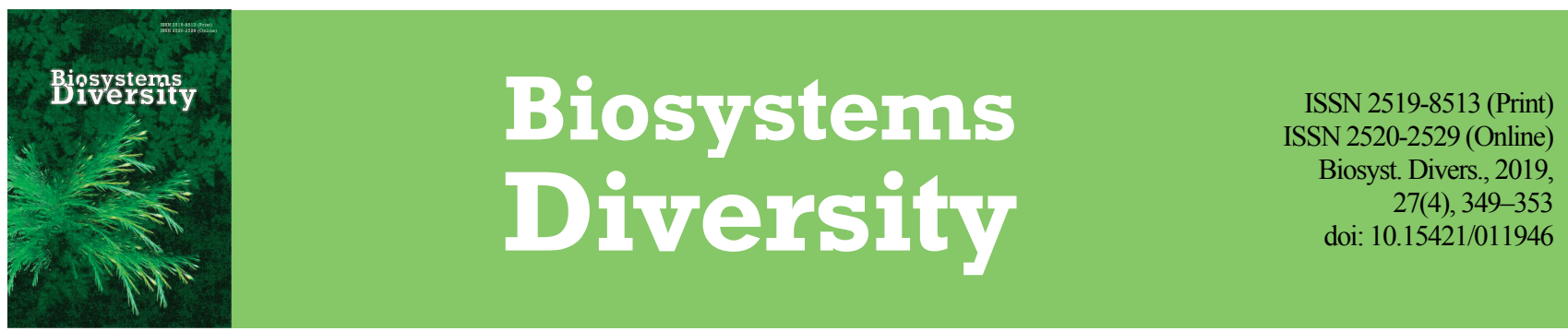

\title{
Repellent and fumigant toxic potential of three essential oils against Ephestia kuehniella
}

\author{
H. Bouzeraa*, M. Bessila-Bouzeraa**, N. Labed*** \\ *Larbi Tebessi University, Tebessa, Algeria \\ **Badji Mokhtar University, Annaba, Algeria \\ ***Chadli Bendjdid University, El Tarf, Algeria
}

Article info

Received 02.11.2019

Received in revised form 24.11.2019

Accepted 25.11.2019

Larbi Tebessi University, Constantine Road, Tebessa, 12002, Algeria.

Tel: 00213-774-060-426.

E-mail:

hayette.bouzeraa@univ-tebessa.dz;

hayettebouzeraa@hotmail.fr

Badji Mokhtar University,

Annaba, BP 12, 23000, Algeria.

Tel: 00213-774-036-655.

E-mail:m.bessilabouzera@yahoo.fr

Chadli Bendjdid University,

El Tarf, Bp 76, 36000, Algeria.

Tel.: 00213-661-453-998.

E-mail:labed.nawel@yahoo.com Bouzeraa, H., Bessila-Bouzeraa, M., \& Labed, N. (2019). Repellent and fumigant toxic potential of three essential oils
against Ephestia kuehniella. Biosystems Diversity, 27(4), 349-353. doi:10.15421/011946

Essential oils, when used as bio-insecticides in the control of insect pests of stored grains have shown specificity and variation in the potentiality of their mode of action. In the present study, three essential oils extracted from three aromatic plants of different families, white wormwood (Artemisia herba alba, Asteraceae), oregano (Origanum vulgare, Lamiaceae) and rue (Ruta montana, Rutaceae), were evaluated for their repellent and fumigant toxic potential against the flour moth larvae, Ephestia kuehniella (Lepidoptera, Pyralidae), under laboratory conditions. The essential oils extraction was done by the hydrodistillation method. The repellent activity was carried out in Petri dishes using a filter paper treated with different oil dilutions $(25,75,100,120,130,150 \mu \mathrm{L} / \mathrm{mL})$. The fumigant toxicity was determined on three concentrations $(50,130$, $150 \mu \mathrm{L} / \mathrm{L}$ air). Two plants were shown to be repellent against the $E$. kuehniella larvae. Origanum oil was the most repellent with $67 \%$ of repellency rate followed by Artemisia oil (46\%) at $120 \mu \mathrm{L} / \mathrm{mL}$ after 2 hours of exposure. The oil of $R$. montana had an attractant activity against the larvae and was the most toxic with $56.7 \%$ of larval mortality in the first 24 hours. The median lethal concentrations $\left(\mathrm{LC}_{50}\right)$ recorded were $11.6,175.4$ and $1100.0 \mu \mathrm{L} / \mathrm{L}$ air for the plant oils $R$. montana, $O$. vulgare and $A$. herba alba, respectively. R. montana and $O$. vulgare essential oil are shown to be efficient with high toxic and repellent properties against $E$. kuehniella larvae. Their specific potential could be integrated in the selection of the best bioinsecticides for the optimum protection of stored grain.

Keywords: stored grains; flour moth; Artemisia herba alba; Ruta montana; Origanum vulgare; insecticidal properties.

\section{Introduction}

Attacks by insect pests of stored grain, in term of quantity and quality of the product, are not negligible. The use of relative synthetic insecticides, on the other hand, is neither safe toward non-target insects nor humans. The US Environmental Protection Agency (USEPA) states that "No adverse effects to humans are expected from the use of plants in repellents and insecticides'(USEPA, 2001) (www.epa.gov/oppbppd1/ biopesticides/ingredients/factsheets/factsheet plant-oils.htm).

Plant essential oils are volatile active substances extracted from aromatic plants that belong to many higher plant families, particularly $\mathrm{Li}$ liaceae, Apiaceae, Pinaceae, Myrtaceae, Lamiaceae, Asteraceae, Rutaceae and Lauraceae. Due to their volatility, essential oils are environmentally non-persistent and 'generally recognized as safe' by the United States Food and Drug Administration (Tripathi et al., 2009). They are, in fact a complex mixture of hydrocarbons and phenylpropanoids. The most frequent hydrocarbons are terpenic compounds, but sesquiterpenes can also be found (Busatta et al., 2007). Concentrations of active chemical compounds often vary between plant family, within the same plant species and between plant parts (leaf, seed, root, fruit, flowers, bark, etc.). These compounds have an important role in the specificity of relationships between insects and their host plants (Huignard, 2008). According to Jayakumar et al. (2017), plants have well developed defence mechanisms against pests due to the intensity of plant-insect interactions, and are excellent sources of new insecticidal substances.

Plant essential oils were reported to have traditionally been used as antioxidants, neurotoxic, antifeedent, growth inhibitors (Huignard, 2008; Chermenskaya et al., 2010; Zanuncio et al., 2016), and, mostly, as a repellent against different insect pests of stored grains (Ikbal et al., 2017). Insec- ticides based on essential oils are very important in control of insect pests because they are active against these species, fast penetrating through the cuticle, leaving no toxic residues in the treated products (Ebadollahi et al., 2010) and they do not have worker re-entry and harvest restrictions after treating crops (Abdel Tawab, 2016).

The degree of the effectiveness of their biological activities depends, mainly, on their chemical components, which vary with the essential oil extraction method, plant phenology, harvesting season, plant part and age, soil and environment (Angioni et al., 2006; Isman et al., 2007). Field efficacy of essential oils is generally less documented for different insect pest species.

The aim of our study was to evaluate the most efficient repellent and toxic activities among different plant essential oils - Artemisia herba alba (Asteraceae), Origanum vulgare (Lamiaceae) and Ruta montana (Rutaceae) - against an important insect pest of stored grains Ephestia kuehniella (Pyralidae).

\section{Materials and methods}

Insect. Ephestia kuehniella larvae were obtained from infected soft wheat flour stock and reared in the laboratory at $25 \pm 3{ }^{\circ} \mathrm{C}, 50 \pm 5 \%$ relative humidity and $8 \mathrm{hrs}$ (light) : $16 \mathrm{hrs}$ (dark). The last instar larvae were collected from the stock colony and used for tests. All the experiments were carried out under the same environmental conditions.

Plant material and oil extraction. The white wormwood, $A$. herba $a l b a$ and the mountain rue, $R$. montana were harvested in the steppe area, Southeast Algeria. The oregano, O. vulgare, was collected in the highlands, North-Central Algeria. The plants were identified at the University of Annaba, Algeria. The aerial parts of the plants were washed 
with dechlorinated water, shade-dried for two weeks and then were cut into small pieces and submitted to oil hydrodistillation.

One hundred grams of dried aerial parts of each plant were boiled in $1.5 \mathrm{~L}$ of distilled water for 4 hours to obtain the distilled volatiles (light to dark yellow oil). Anhydrous Sodium Sulfate $(0.1 \mathrm{~g} / \mathrm{mL}$ oil) was added to absorb water if necessary. The oils were stored in hermetic amber glass vials to reduce evaporative loss and to avoid a reaction with any source of light, and kept in a refrigerator at $4{ }^{\circ} \mathrm{C}$ until when needed for bioassays. The plant essential oils' yield obtained was $2.0 \%$ for A. herba alba, $1.4 \%$ for $R$. montana and $2.9 \%$ for $O$. vulgare.

Repellency test. The experiment was performed on filter paper and a Petri dish of the same diameter $(9 \mathrm{~cm} \varnothing)$. Different concentrations (25, $75,100,120,130$ and $150 \mu \mathrm{L} / \mathrm{mL}$ ) of the essential oils were prepared by dissolving the oil in absolute ethanol for good homogeneity. The filter paper was cut into two halves. One half received $200 \mu \mathrm{L}$ of diluted oil (treated half) and the second half received the same quantity of ethanol (control half). After solvent evaporation, the dried halves were attached lengthwise edge to edge with an odourless adhesive tape and were put in a Petri dish (adhered side at the bottom). Ten larvae were released at the centre of the filter paper and then the Petri dish was sealed tightly to avoid oil evaporation and kept in the dark in the same conditions in the insect rearing. Five replicates were set for each oil concentration. The number of larvae present in both treated and untreated halves of the filter paper was recorded each $30 \mathrm{mn}$ for $2 \mathrm{hrs}$ of the experiment. Percent repellency (PR) of the oils was calculated using the following formula (Talukder \& Howse, 1994):

$$
\operatorname{PR}(\%)=\left(\mathrm{N}_{\mathrm{c}}-\mathrm{N}_{\mathrm{t}}\right) * 100 /\left(\mathrm{N}_{\mathrm{c}}+\mathrm{N}_{\mathrm{t}}\right)
$$

where $\mathrm{N}_{\mathrm{c}}$ - number of larvae on control half, $\mathrm{N}_{\mathrm{t}}$ - number of larvae on treated half.

Preference index (PI) was also calculated using the following formula (Sakuma \& Fukami, 1985):

$$
\mathrm{PI}=\left(\mathrm{N}_{\mathrm{t}}-\mathrm{N}_{\mathrm{c}}\right) /\left(\mathrm{N}_{\mathrm{t}}+\mathrm{N}_{\mathrm{c}}\right)
$$

where $\mathrm{N}_{t}$ - number of larvae in treated half, $\mathrm{N}_{\mathrm{c}}$ - number of larvae in control half.

Fumigant toxicity. The assay was conducted in $125 \mathrm{~mL}$ glass vials. Each essential oil was applied on filter-paper $(2 \mathrm{~cm} ø)$ that was attached to the lower side of the vial's lid. The amounts of essential oils applied were $6.25,16.25$ and $18.75 \mu \mathrm{L}$ corresponding to a concentration of 50 ,
130 and $150 \mu \mathrm{L} / \mathrm{L}$ air, respectively. Ten larvae were put into the vial and were provided with $10 \mathrm{~g}$ of flour as food and then the vials were sealed tightly. Five replicates were set for each oil concentration with complete set of control. The whole experiment was conducted at constant temperature $\left(25 \pm 3{ }^{\circ} \mathrm{C}\right)$, photoperiod $(8 \mathrm{~L}: 16 \mathrm{D})$ and relative humidity $(50 \pm 5 \%)$. The larvae were exposed to the vapours of essential oils for 24, 48 and $72 \mathrm{hrs}$. The number of dead larvae was counted for regular periods of time. The percentage of mortality was calculated using the following formula of Abbott to eliminate natural mortality and to determine the real toxicity of the oil:

Abbott's percent corrected mortality $=\mathrm{M}_{\mathrm{t}}(\%)-\mathrm{M}_{\mathrm{c}}(\%) * 100 / 100-\mathrm{M}_{\mathrm{c}}(\%)$, where $\mathrm{M}_{\mathrm{t}}$ - mortality in treated half, $\mathrm{M}_{\mathrm{c}}$ - mortality in control half.

Statistical analysis. All the data were verified by the Brown-Forsythe test and analyzed by one way ANOVA and Tukey multiple comparisons test. Significant differences between treatments were determined at $\mathrm{P}<0.05$. Probit analysis was done to calculate Median Lethal Concentration $\mathrm{LC}_{50}$. All the data were treated using Graph Pad Prism 7.

\section{Results}

Repellent activity. The results of the plant essential oils' repellent/attractant activity varied with the plant species tested. Significant differences in the ANOVA test were recorded between concentrations in each plant species $(A$. herba alba $-\mathrm{P}<0.0005, \mathrm{~F}=10.01, O$. vulgare $-\mathrm{P}<$ $0.0005, \mathrm{~F}=12.57 ;$ R. montana $-\mathrm{P}<0.0005, \mathrm{~F}=14.14)$. According to the index of preference, the negative values indicated that $A$. herba alba and $O$. vulgare were repellent against $E$. kuehniella during 30, 60, 90 and $120 \mathrm{mn}$ (Fig. 1). At the concentration of $120 \mu \mathrm{L} / \mathrm{mL}, O$. vulgare exhibited the highest repellency rate recorded at $67 \%$, followed by A. herba alba (46\%) after two hours of exposure (Table 1). The most repellent oil was $O$. vulgare. However, $R$. montana exhibited attractant effect according to preference index. In general, the activity of the plant essential oils increases with an increase in concentration. In this study, the results showed the activity decreased from the concentrations $120 \mu \mathrm{L} / \mathrm{mL}$ for $A$. herba alba and $O$. vulgare and $25 \mu \mathrm{L} / \mathrm{mL}$ for $R$. montana. The lack of repellent and attractant effect was observed at high concentrations 150 and $130-150 \mu \mathrm{L} / \mathrm{mL}$ for $A$. herba alba and $R$. montana, respectively.
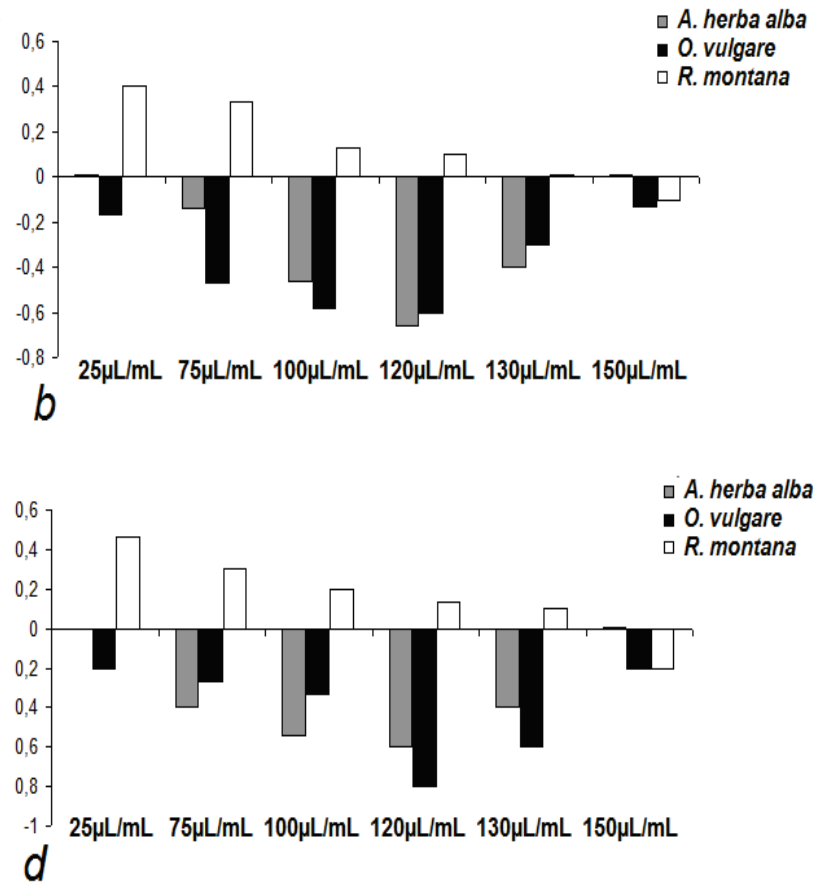

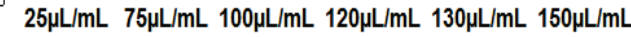

Fig. 1. Effects of essential oils on preference index of Ephestia kuehniella larvae in time:

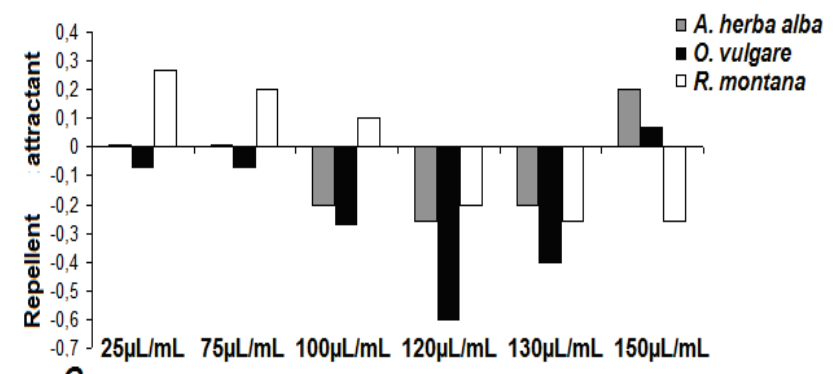
C

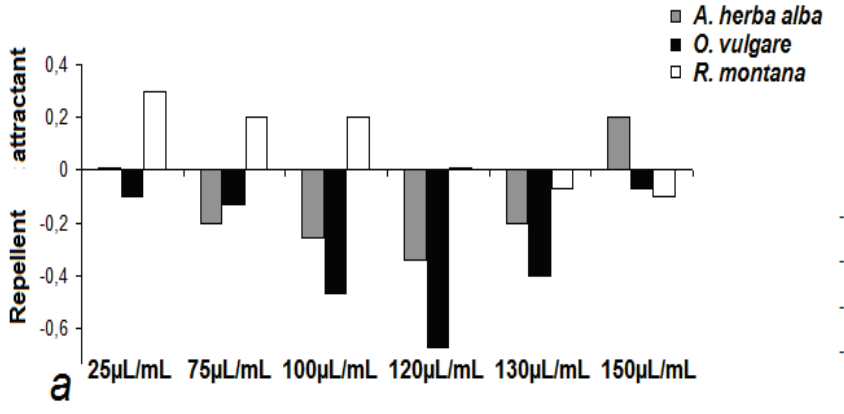

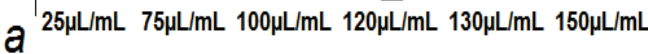


Table 1

Mean repellency rate and preference index of Ephestia kuehniella larvae toward the plant essential oils

\begin{tabular}{|c|c|c|c|c|}
\hline Plants & $\begin{array}{l}\text { Oil concent- } \\
\text { rations, } \mu \mathrm{L} / \mathrm{mL}\end{array}$ & $\begin{array}{l}\text { Mean repel- } \\
\text { lency rate, \% }\end{array}$ & $\begin{array}{c}\text { Repellency } \\
\text { class }\end{array}$ & $\begin{array}{l}\text { Preference } \\
\text { index }(\mathrm{PI})\end{array}$ \\
\hline & 25 & $0^{\mathrm{ab}}$ & 0 & 0.00 \\
\hline & 75 & $18^{\mathrm{abc}}$ & 1 & -0.18 \\
\hline A. herba & 100 & $36^{\mathrm{c}}$ & 2 & -0.36 \\
\hline \multirow[t]{5}{*}{ alba } & 120 & $46^{\mathrm{c}}$ & 3 & -0.46 \\
\hline & 130 & $30^{\mathrm{bc}}$ & 2 & -0.30 \\
\hline & 150 & $-10^{\mathrm{a}}$ & 0 & 0.10 \\
\hline & 25 & $13^{\mathrm{ab}}$ & 1 & -0.13 \\
\hline & 75 & $23^{\mathrm{abc}}$ & 2 & -0.23 \\
\hline$O$ & 100 & $41^{\mathrm{bcd}}$ & 3 & -0.41 \\
\hline \multirow[t]{5}{*}{ vulgare } & 120 & $67^{\mathrm{d}}$ & 4 & -0.67 \\
\hline & 130 & $42^{\text {cd }}$ & 3 & -0.42 \\
\hline & 150 & $8^{\mathrm{a}}$ & 1 & -0.08 \\
\hline & 25 & $-35^{\mathrm{a}}$ & 0 & 0.35 \\
\hline & 75 & $-27^{\mathrm{a}}$ & 0 & 0.27 \\
\hline$R$ & 100 & $-16^{\mathrm{ab}}$ & 0 & 0.16 \\
\hline \multirow[t]{3}{*}{ montana } & 120 & $0^{\mathrm{bc}}$ & 0 & 0.00 \\
\hline & 130 & $5^{\mathrm{bc}}$ & 1 & -0.05 \\
\hline & 150 & $16^{\mathrm{c}}$ & 1 & -0.10 \\
\hline
\end{tabular}

Note: numbers of mean repellency rate $(\%)$ in the same column for each plant followed by the same letters do not differ significantly $(P>0.05)$ in the Tukey test.

Fumigant toxicity. The plant essential oils tested exhibit toxic activity against $E$. kuehniella. The mortality recorded increased with an increase in concentration in treatment and in time (Table 2). Significant differences between the plant essential oils in the ANOVA test were recorded. In the first $24 \mathrm{hrs}$, high toxic potential was observed in $R$. montana $(56.7 \%$ mortality) at low concentration $(50 \mu \mathrm{L} / \mathrm{L}$ air), and $76.7 \%$ mortality was recorded at high concentration $(150 \mu \mathrm{L} / \mathrm{L}$ air), followed by $O$. vulgare with $20 \%$ and $50 \%$ mortality, respectively. A. herba alba showed the lowest toxicity with only $6.7 \%$ mortality at high concentration $(150 \mu \mathrm{L} / \mathrm{L}$ air $)$ compared to rue and origano oil. According to the result, in descending order, the toxic potential of the oils was $R$. montana $\left(\mathrm{LC}_{50}=11.64 \mu \mathrm{L} / \mathrm{L}\right.$ air $/ 24 \mathrm{hrs})>O$. vulgare $\left(\mathrm{LC}_{50}=175.4 \mu \mathrm{L} / \mathrm{L}\right.$ air/24hrs $)>A$. herba alba $\left(\mathrm{LC}_{50}=1100 \mu \mathrm{L} / \mathrm{L}\right.$ air $\left./ 24 \mathrm{hrs}\right)$ (Table 3).

Table 2

Percent mortality of Ephestia kuehniella larvae exposed to the plant essential oils during 24, 48 and $72 \mathrm{hrs}$

\begin{tabular}{lcccc}
\hline Plant oil name e & $\begin{array}{c}\text { Concentrations, } \\
\mu \mathrm{L} / \mathrm{L} \text { air }\end{array}$ & 24 & 48 & 72 \\
\hline A. herba alba & 50 & $0.00 \pm 0.00^{\mathrm{c}}$ & $6.67 \pm 4.71^{\mathrm{c}}$ & $10.00 \pm 0.00^{\mathrm{b}}$ \\
O. vulgare & 50 & $20.00 \pm 8.16^{\mathrm{b}}$ & $36.67 \pm 9.43^{\mathrm{b}}$ & $60.00 \pm 21.60^{\mathrm{a}}$ \\
R. montana & 50 & $56.67 \pm 4.71^{\mathrm{a}}$ & $66.67 \pm 4.71^{\mathrm{a}}$ & $73.33 \pm 12.47^{\mathrm{a}}$ \\
& & $P<0.0005$ & $P<0.0005$ & $P=0.01$ \\
& & $F=55.75$ & $F=45.50$ & $F=10.75$ \\
\hline A. herba alba & 130 & $3.33 \pm 4.71^{\mathrm{c}}$ & $13.33 \pm 4.71^{\mathrm{b}}$ & $26.67 \pm 9.43^{\mathrm{b}}$ \\
O. vulgare & 130 & $33.33 \pm 9.43^{\mathrm{b}}$ & $56.67 \pm 12.47^{\mathrm{a}}$ & $70.00 \pm 14.14^{\mathrm{a}}$ \\
R. montana & 130 & $66.67 \pm 4.71^{\mathrm{a}}$ & $76.67 \pm 12.47^{\mathrm{a}}$ & $83.33 \pm 9.43^{\mathrm{a}}$ \\
& & $P<0.0005$ & $P=0.003$ & $P=0.006$ \\
& & $F=45.17$ & $F=18.87$ & $F=13.94$ \\
\hline A. herba alba & 150 & $6.66 \pm 4.71^{\mathrm{c}}$ & $16.67 \pm 4.71^{\mathrm{b}}$ & $33.33 \pm 4.71^{\mathrm{b}}$ \\
O. vulgare & 150 & $50.00 \pm 8.16^{\mathrm{b}}$ & $73.33 \pm 4.71^{\mathrm{a}}$ & $93.33 \pm 9.43^{\mathrm{a}}$ \\
R. Montana & 150 & $76.67 \pm 4.71^{\mathrm{a}}$ & $83.33 \pm 4.71^{\mathrm{a}}$ & $86.67 \pm 4.71^{\mathrm{a}}$ \\
& & $P<0.0005$ & $P<0.0005$ & $P<0.0005$ \\
& & $F=67.40$ & $F=116.33$ & $F=36.0$ \\
\hline
\end{tabular}

Note: values represent mean $\pm \mathrm{SD}$; similar letters in a column in a row do not differ significantly using the Tukey test $(\mathrm{P}>0.05)$.

\section{Discussion}

Essential oils are the alternative natural chemical products to synthetic pesticides (Boyko \& Brygadyrenko, 2016, 2017). Because of their insecticidal effects and, besides, their lower toxic effect on nontarget organisms and low-risk to the environment, they have been the most favoured in the pest management programmes globally. Plant essential oils have been a subject of research on their various modes of action as a deterrent, repellent, attractant, toxic and by disrupting reproductive and developmental processes through contact, ingestion or fumigant. The plants selected in this study were reported by Jacobson (1989) to be among the plant families with the most efficient major compounds against insect pests. However, many botanicals in anthropogenic habitats are yet to be exploited for their insecticidal activities, and have been reported to be specific to insect species (Bouzeraa et al., 2018).

Table 3

$\mathrm{LC}_{50}$ values of the plant essential oils against Ephestia kuehniella after 24,48 and $72 \mathrm{hrs}$ of exposure

\begin{tabular}{cccccc}
\hline Plants & $\begin{array}{c}\text { Time, } \\
\mathrm{h}\end{array}$ & $\begin{array}{c}\mathrm{LC} 50, \mu \mathrm{L} / \mathrm{L} \text { air } \\
95 \% \text { confidence limits }\end{array}$ & $\mathrm{R}^{2}$ & $\mathrm{DF}$ & $\mathrm{x} \pm \mathrm{SE}$ \\
\hline \multirow{3}{*}{ A. herba alba } & 24 & $1100.0(877.4-1568)$ & 0.98 & 3 & $1.38 \pm 0.10$ \\
& 48 & $927.80(709.5-1415)$ & 0.98 & 3 & $0.96 \pm 0.07$ \\
& 72 & $448.80(301.1-981.3)$ & 0.95 & 3 & $0.79 \pm 0.12$ \\
O. vulgare & 24 & $175.40(132.8-283.4)$ & 0.94 & 5 & $1.05 \pm 0.18$ \\
& 48 & $63.23(33.7-111.8)$ & 0.87 & 5 & $0.86 \pm 0.19$ \\
& 72 & $12.34(0.6-32.93)$ & 0.73 & 5 & $0.58 \pm 0.18$ \\
R. montana & 44 & $11.64(1.6-25.85)$ & 0.83 & 4 & $0.32 \pm 0.07$ \\
& 48 & $02.45(0.03-07.27)$ & 0.83 & 4 & $0.30 \pm 0.07$ \\
& 72 & $0.68(0.001-02.91)$ & 0.83 & 4 & $0.28 \pm 0.06$ \\
\hline
\end{tabular}

Attractant and repellent properties are an important process for grain storage protection against insects. The repellent plants lead to an inappropriate behavioural response of the insects that change their direction far from the storage area; while the attractant properties of plants cause insects to make oriented movements to the plants' odour, keeping the insect pests away from a grain source.

PI value gives an idea about the repellency or attractancy of a chemical substance against a tested animal (Paulraj \& Sahayaraj, 2002). In this study, the plant essential oils had a repellent and an attractant activity against E. kuehniella larvae, at minimum exposure time. The potentiality degree of the insect response is dependent on the oil concentrations and the plant species related to the chemical composition of the essential oils. It has been reported that an insect exposed to the chemical signal selectively responds to the active components in the signal (Torto, 2011).

The presence of monoterpenoids, sesquiterpenes, and alcohols have been proven to be attributes of the repellent properties of essential oils (Sritabutra \& Soonwera, 2013; Sathantriphop et al., 2015 Martynov et al., 2019). Taylor et al. (2012) and Dickens \& Bohbot (2013) showed that the odorant receptor neuron in a mosquito's antennal sensilla is activated by linalool, a naturally occurring terpene alcohol and by eucalyptol, a natural organic compound. In particular, citronellol, citronellal, $\alpha$-pinene, and limonene are the common constituents of many essential oils exhibiting repellent effects (Tong \& Bloomquist, 2013; SoleimaniAhmadi et al., 2017). Other components such as p-cymene, 1,8-cineole, linalool, salicylaldehyde, geraniol, cis-jasmone attract several insect species when the essential oils are added to traps (Pair \& Horvat, 1997; Katerinopoulos et al., 2005). It has been reported that insects' sensory systems have the ability to adjust their sensitivity to the different intensities of a stimulus (Zufall \& Leinders-Zufall, 2000).

According to Huotari et al. (2003), the effects of attractant and repellent odours may be competing in different olfactory receptor neurons. In our study, the filter paper method of testing the response behaviour of the insect to each essential oil indicates that the attractant and repellent behaviour of E. kuheniella larvae may be related to the sensitivity of olfactory receptors to some oil components more than others, so it becomes an attractive or repellent signal. This may be explained by the fact that the repellent components could activate the neuron olfactive receptors which couldn't support the stimulation and, further, that they respond by a sensitive reaction, or, as suggested by Davis (1985), by a reverse perception of the attractant signal to an irritant message.

Several studies of plant volatile and their constituents have shown them to effectively disrupt the recognition process of the host substrate and influence the walking behaviour of insects (Verheggen et al., 2007; Germinara et al., 2015). In this study, the high oil concentrations disrupted the behaviour of E. kuheniella larvae. The larvae were shown to 
be unaware and their behaviour was confused. The olfactory receptor neurons could be saturated, so that the message resulting from the central nervous system via cellular and metabolite activity may be inhibited when in turn muscles, whose action manifests as a behavioural response, could be inactivated. As suggested previously, the reduction of responsiveness may be due to an alteration of the locomotion activity at higher concentrations at which the behaviour was disrupted and the larvae responded to the toxic effect of the oil (Bouzeraa et al., 2018).

Oils fumigant exposure, whether attractant or repellent, is toxic to target insects at high concentrations and over time. The message relayed by chemoreceptors entails long-term irreversible physiological or biochemical changes (Torto, 2011). In our study, R. montana oil exhibited high toxic potential by fumigant against the insect larvae. The toxic effect manifests by a reduction of their walking behaviour followed by suffocation and death. Larvae breathe through spiracles and therefore come to the surface frequently (Kaufmann \& Briegel, 2004) to breathe. The plant extracts used in this study are oily; hence, the oils could block the spiracles, resulting in asphyxiation and death of the larvae (Akinkurolere et al., 2006; Adedire et al., 2011).

Further, Emekci et al. (2004) suggest that monoterpenes can affect many targets in insects with numerous mechanisms of toxicity. Rattan (2010) reviewed the mechanism of action of essential oils on the body of insects and documented several physiological disruptions.

Several studies showed that most essential oils comprise monoterpenes compounds which bind to protein receptors and act by inhibiting acetylcholinesterase enzyme (AChE) (Chaubey, 2014, 2017), interfering with the neuromodulator octopamine (Enan, 2005) or GABA-gated chloride channels (Priestley et al., 2006) and interrupting neurotransmission, leading to physiological imbalance and, thereafter, death of the target insect.

\section{Conclusions}

The results are in accordance with earlier studies and confirm that plant essential oils are good bioinsecticides for protection of stored grain. Their specificity suggests that extensive research should be conducted to increase understanding of their mode of action, which must continue to be investigated, and integrated in pest management programmes.

\section{References}

Abdel-Tawab, H. M. (2016). Green pesticides: Essential oils as biopesticides in insect-pest management. Journal of Environmental Science and Technology, 9(5), 354-378.

Adedire, C. O., Obembe, O. M., Akinkurolere, R. O., \& Oduleye, S. O. (2011). Response of Callosobruchus maculatus Fabricius (Coleoptera: Chrysomelidae: Bruchinae) to extracts of cashew kernels. Journal of Plant Diseases and Protection, 118(2), 75-79.

Akinkurolere, R. O., Adedire, C. O., \& Odeyemi, O. O. (2006). Laboratory evaluation of the toxic properties of forest Anchomanes, Anchomanes difformis against pulse beetles Callosobruchus maculatus (Coleoptera: Bruchidae). Insect Science, 13(1), 25-29.

Angioni, A., Barra, A., Coroneo, V., Dessi, S., \& Cabras, P. (2006). Chemical composition, seasonal variability and antifungal activity of Lavandula stoechas $\mathrm{L}$. ssp. stoechas essential oils from stem/leaves and flowers. Journal of Agricultural and Food Chemistry, 54(12), 43644370.

Bouzeraa, H., Bessila-Bouzeraa, M., Labed, N., Sedira, F., \& Ramdani, L. (2018). Evaluation of the insecticidal activity of Artemisia herba alba essential oil against Plodia interpunctella and Ephestia kuehniella (Lepidoptera, Pyralidae). Journal of Entomology and Zoology Studies, 6(5), 145-150.

Boyko, A. A., \& Brygadyrenko, V. V. (2016). Influence of water infusion of medicinal plants on larvae of Strongyloides papillosus (Nematoda, Strongyloididae). Visnyk of Dnipropetrovsk University. Biology, Ecology, 24(2), 519-525.

Boyko, A. A., \& Brygadyrenko, V. V. (2017). Changes in the viability of Strongyloides ransomi larvae (Nematoda, Rhabditida) under the influence of synthetic flavourings. Regulatory Mechanisms in Biosystems, 8(1), 36-40.

Busatta, C., Mossi, A. J., Rodrigues, M. R. A., Cansian, R. L., \& de Oliveira, J. V. (2007). Evaluation of Origanum vulgare essential oil as antimicrobial agent sausage. Brazilian Journal of Microbiology, 38(4), 610-616.
Chaubey, M. K. (2014). Biological activities of Allium sativum essential oil against pulse beetle, Callosobruchus chinensis (Coleoptera: Bruchidae). Herba Polonica, 60(2), 41-55.

Chaubey, M. K. (2017). Fumigant and contact toxicity of Allium sativum (Alliaceae) essential oil against Sitophilus oryzae L. (Coleoptera: Dryophthoridae). Entomology and Applied Science Letters, 3(2), 43-48.

Chermenskaya, T. D., Stepanycheva, E. A., Shchenikova, A. V., \& Chakaeva, A. S. (2010). Insecto acaricidal and deterrent activities of extracts of Kyrgyzstan plants against three agricultural pests. Industrial Crops and Products, 32(2), 157-163.

Davis, E. E. (1985). Insect repellents: Concepts of their mode of action relative to potential sensory mechanisms in mosquitoes (Diptera: Culicidae). Journal of Medical Entomology, 22(3), 237-243

Dickens, J. C., \& Bohbot, J. D. (2013). Mini review: Mode of action of mosquito repellents. Pesticide Biochemistry and Physiology, 106(3), 149-155.

Ebadollahi, A., Safaralizadeh, M. H., \& Pourmirza, A. A. (2010). Fumigant toxicity of Lavandula stoechas L. oil against three insect pests attacking stored products. Journal of Plant Protection Research, 50(1), 56-60.

Emekci, M., Navarro, S., Donahaye, E., Rindner, M., \& Azrieli, A. (2004). Respiration of Rhyzopertha dominica (F.) at reduced oxygen concentrations. Journal of Stored Products Research, 40(1), 27-38.

Enan, E. E. (2005). Molecular and pharmacological analysis of an octopamine receptor from American cockroach and fruit fly in response to plant essential oils. Archives of Insect Biochemistry and Physiology, 59(3), 161-171.

Germinara, G. S., Cristofaro, A., \& Rotundo, G. (2015). Repellents effectively disrupt the olfactory orientation of Sitophilus granarius to wheat kemels. Journal of Pest Science, 88(4), 675-684.

Huignard, J., Dugravot, S., Ketoh, K. G., Thibout, E., \& Glitho, A. I. (2002). Utilisation de composés secondaires des végétaux pour la protection des graines d'une légumineuse, le niébé. Conséquences sur les insectes ravageurs et leurs parasitoides. In: Regnault-Roger, C., Philogène, B. J. R., \& Vincent, C. (Ed.). Biopesticides d'Origine Végétale. Lavoisier Tech \& Doc, Paris. Pp. 133-149.

Huotari, M., Jaskari, M., Annila, E., \& Lantto, V. (2003). Responses of olfactory receptor neurons of the large pine weevil to a possible deterrent Neutroil ${ }^{\mathbb{R}}$ and two other chemicals. Silva Fennica, 37(1), 149-156.

Ikbal, C., Ben-Hamouda, A., Tayeb, W., Zarrad, K., Bouslema, T., \& Laarif, A. (2017). The Tunisian Artemisia essential oil for reducing contamination of stored cereals by Tribolium castaneum. Food Technology and Biotechnology, 56(2), 247-256.

Isman, M. B., Machial, C. M., Miresmailli, S., \& Bainard, L. D. (2007). Essential oil-based pesticides: New insights from old chemistry. In: Ohkawa, H., Miyagawa, H., \& Lee, P. W. (Eds.). Pesticide chemistry crop protection, public health, environmental healthy. Wiley-VCH, Weinheim. Pp. 201-209.

Jacobson, M. (1989). Botanical pesticides: Past, present, and future. In: Arnason, J. T., Philogene, B. J. R., \& Morand, P. (Eds.). Insecticides of plant origin. ACS Symposium Series No. 387. American Chemical Society, Washington. Pp. 1-10.

Jayakumar, M., Arivoli, S., Raveen, R., \& Tennyson, S. (2017). Repellent activity and fumigant toxicity of a few plant oils against the adult rice weevil Sitophilus oryzae Linnaeus 1763 (Coleoptera: Curculionidae). Journal of Entomology and Zoology Studies, 5(2), 324-335.

Katerinopoulos, H. E., Pagona, G., Afratis, A., Stratigakis, N., \& Roditakis, N. (2005). Composition and insect attracting activity of the essential oil of Rosmarinus officinalis. Journal of Chemical Ecology, 31(1), 111-122.

Kaufmann, C., \& Briegel, H. (2004). Flight performance of the malaria vectors Anopheles gambiae and Anopheles atroparous (CPDF). Journal of Vector Ecology, 29(1), 140-153.

Martynov, V. O., Titov, O. G., Kolombar, T. M., \& Brygadyrenko, V. V. (2019). Influence of essential oils of plants on themigration activity of Tribolium confusum (Coleoptera, Tenebrionidae). Biosystems Diversity, 27(2), 177-185.

Pair, S. D., \& Horvat, R. J. (1997). Volatiles of Japanese honeysuckle flowers as attractants for adult lepidopteran insects. US Patent No. 5665344, September 9, washington DS.

Paulraj, M. G., \& Sahayaraj, K. (2002). Efficacy of Eclipta alba (L.) Hassk and Ocimum sanctum (L.) leaves extracts and powders against Tribolium castaneum (Herbst) (Coleoptera: Tenebrionidae) in groundnut. In: Sanjayan, K. P., Mahalingam, V., \& Muralirangan, M. C. (Eds.). Vistas of entomological research for the new millenium. Gill Research Institute, Chennai. Pp. 80.

Priestley, C. M., Burgess, I. F., \& Williamson, E. M. (2006). Lethality of essential oil constituents towards the human louse, Pediculus humanus and its eggs. Fitoterapia, 77(4), 303-309.

Rattan, R. S. (2010). Mechanism of action of insecticidal secondary metabolites of plant origin. Crop Protection, 29(9), 913-920.

Sakuma, M., \& Funkami, H. (1985). The linear track olfactometer: An assay device for taxes of the german cockroach, Blattella germanica (Linn.) toward their aggregation pheromone. Applied Entomology and Zoology, 74(6), 523-525. 
Sathantriphop, S., Achee, N. L., Sanguanpong, U., \& Chareonviriyaphap, T. (2015). The effects of plant essential oils on escape response and mortality rate of Aedes aegypti and Anopheles minimus. Journal of Vector Ecology, 40(2), 318-326.

Soleimani-Ahmadi, M., Abtahi, S. M., Madani, A., Paksa, A., Abadi, Y. S., Gorouhi, M. A., \& Sanei-Dehkordi, A. (2017). Phytochemical profile and mosquito larvicidal activity of the essential oil from aerial parts of Satureja bachtiarica Bunge against malaria and lymphatic filariasis vectors. Journal of Essential Oil Bearing Plants, 20(2), 328-336.

Sritabutra, D., \& Soonwera, M. (2013). Repellent activity of herbal essential oils against Aedes aegypti (Linn.) and Culex quinquefasciatus (Say.). Asian Pacific Journal of Tropical Disease, 3(4), 271-276.

Talukder, F. A., \& Howse, P. E. (1994). Laboratory evaluation of toxic repellent properties of the pithraj tree, Aphanamixis polystachya Wall \& Parker, against Sitophilus oryzae (L.). International Joumal of Pest Management, 40(3), 274-279.

Taylor, R. W., Romaine, I. M., Liu, C., Murthi, P., Jones, P. L., Waterson, A. G., Sulikowski, G. A., \& Zwiebel, L. J. (2012). Structure-activity relationship of a broad-spectrum insect odorant receptor agonist. ACS Chemical Biology, 7(10), 1647-1652.
Tong, F., \& Bloomquist, J. R. (2013). Plant essential oils affect the toxicities of carbaryl and permethrin against Aedes aegypti (Diptera: Culicidae). Journal of Medical Entomology, 50(4), 826-832.

Torto, B. (2011). Chemical signals as attractants, repellents and aggregation stimulants. Chemical Ecology. In: Hardege, J. D. (Ed.). Encyclopedia of life support systems. Developed under the auspices of the UNESCO. EOLSS Publishers, Oxford. Pp. 186-199.

Tripathi, A. K., Upadhyay, S., Bhiyan, M., \& Bhattacharya, P. R. (2009). A review on prospects of essential oils as biopesticide in insect-pest management. Journal of Pharmacognosy and Phytotherapy, 1(5), 52-63.

Verheggen, F., Ryne, C., Olsson, P. O., Arnaud, L., Lognay, G., Högberg, H. E., Persson, D., Haubruge, E., \& Löfstedt, C. (2007). Electrophysiological and behavioral activity of secondary metabolites in the confused flour beetle, Tribolium confusum. Journal of Chemical Ecology, 33, 525-539.

Zanuncio, J. C., Mourão, S. A., Martínez, L. C., Wilcken, C. F., Ramalho, F. S., Plata-Rueda, A., Soares, M. A., \& Serrão, J. E. (2016). Toxic effects of the neem oil (Azadirachta indica) formulation on the stink bug predator, Podisus nigrispinus (Heteroptera: Pentatomidae). Scientific Reports, 6(6), 30261.

Zufall, F., \& Leinders-Zufall, T. (2000). The cellular and molecular basis of odor adaptation. Chemical Senses, 25(4), 473-481. 